\title{
HYDROGEN EMBRITTLEMENT of
} IRRADIATED ALLOYS

This report was prepared as an account of work sponsored by the United States Government. Neither the United States nor the United States Energy Research and Development Administration, nor any of their employees, nor any of their contractors, subcontractors, or their employees, makes any warranty, express or implied, or assumes any legal liability or responsibility for the accuracy, completeness or usefulness of any information, apparatus, product or process disclosed, or represents that its use would not infringe privately owned rights.
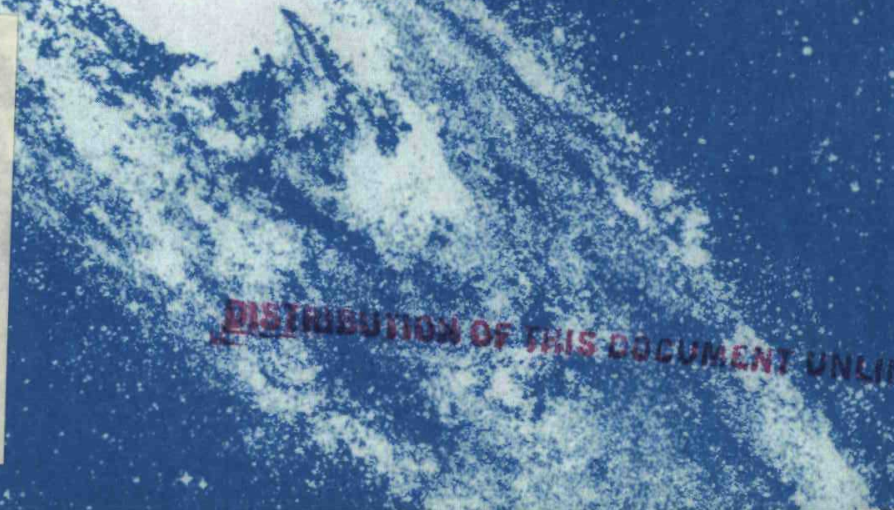

4 ;

\section{NUCLEAR AEROSPACE RESEARCH FACILITY}




\section{DISCLAIMER}

This report was prepared as an account of work sponsored by an agency of the United States Government. Neither the United States Government nor any agency Thereof, nor any of their employees, makes any warranty, express or implied, or assumes any legal liability or responsibility for the accuracy, completeness, or usefulness of any information, apparatus, product, or process disclosed, or represents that its use would not infringe privately owned rights. Reference herein to any specific commercial product, process, or service by trade name, trademark, manufacturer, or otherwise does not necessarily constitute or imply its endorsement, recommendation, or favoring by the United States Government or any agency thereof. The views and opinions of authors expressed herein do not necessarily state or reflect those of the United States Government or any agency thereof. 


\section{DISCLAIMER}

Portions of this document may be illegible in electronic image products. Images are produced from the best available original document. 


\section{NUCLEAR AEROSPACE RESEARCH FACILITY}

\section{HYDROGEN EMBRITTLEMENT \\ of}

IRRADIATED ALLOYS

J. K. Miles

R. L. Burtnett

GENERAL DYNAMICS

Fort Worth Division 


\section{FOREWORD}

The radiation effects/hydrogen embrittlement study described in this document was performed at the Nuclear Aerospace Research Facility of the Convair Aerospace Division of General Dynamics for the Space Nuclear Systems office, Cleveland, Ohio (SNSO-C) under Contract SNPC-73, Modification No. 3.

Test specimens and test specifications were provided by AerojetGeneral Corporation (AGC), Sacramento, California, and Westinghouse Astronuclear Laboratory (WANL), Pittsburgh, Pennsylvania. The test specimens were irradiated by the National Aeronautics and Space Administration, Lewis Research Center, Plum Brook Station, Sandusky, Ohio.

This document contains a complete description of the test specimens, experimental equipment, and test procedures in addition to a presentation and discussion of the experimental results. 
PAGE BLANK 


\section{ABS TRACT}

The effects of gaseous hydrogen at 1500 psi and room temperature were studied on the notch tensile strengths of four types of alloys - 301 SS, A-286, Ti 5A1 2.5Sn, and Incone1 718 which had been previously irradiated to neutron fluences of $1.3-1.6 \times 10^{20} \mathrm{n} / \mathrm{cm}^{2}(E>1 \mathrm{MeV})$. The reductions in notch tensile strength of $301 \mathrm{SS}, 81 \%$; Ti $5 \mathrm{Al} 2.5 \mathrm{Sn}, 7.3 \%$; and A-286, unchanged, were in good agreement with those expected for similar specimens which were unirradiated. The notch tensile strength of irradiated Inconel 718 specimens was unaffected by hydrogen, while control specimens exhibited $8-9 \%$ losses in strength. 
PAGE BLANK 
FOREWORD

ABS TRACT

$\mathrm{v}$

LIST OF FIGURES

ix

LIST OF TABLES

xi

I. INTRODUCTION

II. TEST DESCRIPTION 3

2.1 Test Specimens 3

2.2 Irradiation 8

2.3 Experimental Apparatus 10

2.4 Test Procedures 14

III. RESULTS AND CONCLUSIONS 18

$\begin{array}{llll}3.1 & \text { Ti } 5 \mathrm{Al} 2.5 \mathrm{Sn} & 18\end{array}$

$\begin{array}{lll}3.2 \mathrm{~A}-286 & 19\end{array}$

$\begin{array}{lll}3.3 & 301 \text { SS } & 20\end{array}$

3.4 Inconel $718 \quad 21$

IV. REFERENCES 26 
PAGE BLANK 


\section{LIST OF FIGURES}

Figure No.

1

2

3

4

5
Title

Design of Buttonhead Specimens

Design of Sheet Specimens

Test Chamber Mounted on Loading Assembly

Schematic of Gas Distribution System

Buttonhead Specimen Loaded in Test Chamber
Page

4

6

12

13

15 
PAGE BLANK 


\section{LIST OF TABLES}

Table No.

I

II

III

IV

V

VI

VII

VIII

IX

$\mathrm{X}$

Title

$\underline{\text { Page }}$

Notch Dimensions of Buttonhead Specimens 5

Notch Dimensions of 301 SS Specimens

7

Chemical Compositions of Test Specimens

7

Heat Treatments of Test Specimens

8

Neutron Fluences Received by Test Specimens

9

Notch Tensile Strengths of Irradiated

Ti $5 A 12.5$ Sn Specimens

18

Notch Tensile Strengths of Irradiated A-286 Specimens

Notch Tensile Strengths of Irradiated 301 SS Specimens

Notch Tensile Strengths of Irradiated Inconel 718 Specimens

Summary of Hydrogen-Embrittlement Data on Unirradiated Inconel 718 


\section{INTRODUCTION}

This program was conducted to investigate the combined effects of high-pressure hydrogen gas and reactor radiation on the notch tensile strengths of four materials being considered for use in the propellant feed system of the NERVA: Inconel 718, 301 SS, A-286, and $\mathrm{Ti} 5 \mathrm{Al} 2.5 \mathrm{Sn}$. Tensile tests were performed at ambient temperatures at a pressure of $1500 \mathrm{psi}$. The test specimens were irradiated in the NASA/Plum Brook reactor to a nominal fluence of $1.5 \times 10^{20} \mathrm{n} / \mathrm{cm}^{2}$ (E>1 MeV).

No data are available in the literature on the hydrogen embrittlement of irradiated alloys of these types. The embrittlements of unirradiated specimens of Inconel 718 , Ti $5 \mathrm{Al} 2.5 \mathrm{Sn}$, and A-286 have been studied previous1y, however.

Reductions in the notch tensile strength of Inconel 718 varying from $9.1 \%$ to $54 \%$ have been reported (Refs, $1,2,3$ ). The degree of hydrogen embrittlement of Inconel 718 was observed to increase with increasing hydrogen pressure. The data also indicate that the degree of embrittlement decreases with increasing solution annealing temperature.

The notch tensile strength of $\mathrm{Ti} 5 \mathrm{Al} 2.5 \mathrm{Sn}$ has been observed to undergo losses of $19 \%$ at a hydrogen pressure of 10,000 psi (Ref. 1) and $10 \%$ at 1400 psi (Ref. 3). 
Specimens of A-286 have been reported to 1ose $3 \%$ in notch tensile strength at a hydrogen pressure of 10,000 psi (Ref. 1) and to be unaffected at 1400 psi (Ref. 3).

No data have appeared in the literature on the effects of high-pressure hydrogen on 301 SS. 


\section{TEST DESCRIPTION}

The purpose of this test was to determine the effects of gaseous hydrogen at $1500 \mathrm{psi}$ and ambient temperatures on the notch tensile strength of four irradiated alloys. The test specifications were prepared by the project sponsor, Aerojet-General Corporation, and are listed below for each material type:

Material

Ti $5 \mathrm{~A} 12.5 \mathrm{Sn}$

Inconel 718

A-286

301 SS
Test Specification

37 NRO 090

37 NRO 091

37 NRO 092

37 NRO 093

The tensile tests were performed by utilizing a stainless steel pressure chamber in conjunction with an Instron test machine. High-purity hydrogen was obtained by passing bottled hydrogen through a purification system before introduction into the test chamber.

A detailed description of the specimens, apparatus, and test procedures are presented in this section.

\subsection{Test Specimens}

The A-286, Inconel 718, and $\mathrm{Ti} 5 \mathrm{Al} 2.5 \mathrm{Sn}$ specimens were supplied by AGC. These specimens were of the notched buttonhead design shown in Figure 1. The 301 SS specimens were supplied by 


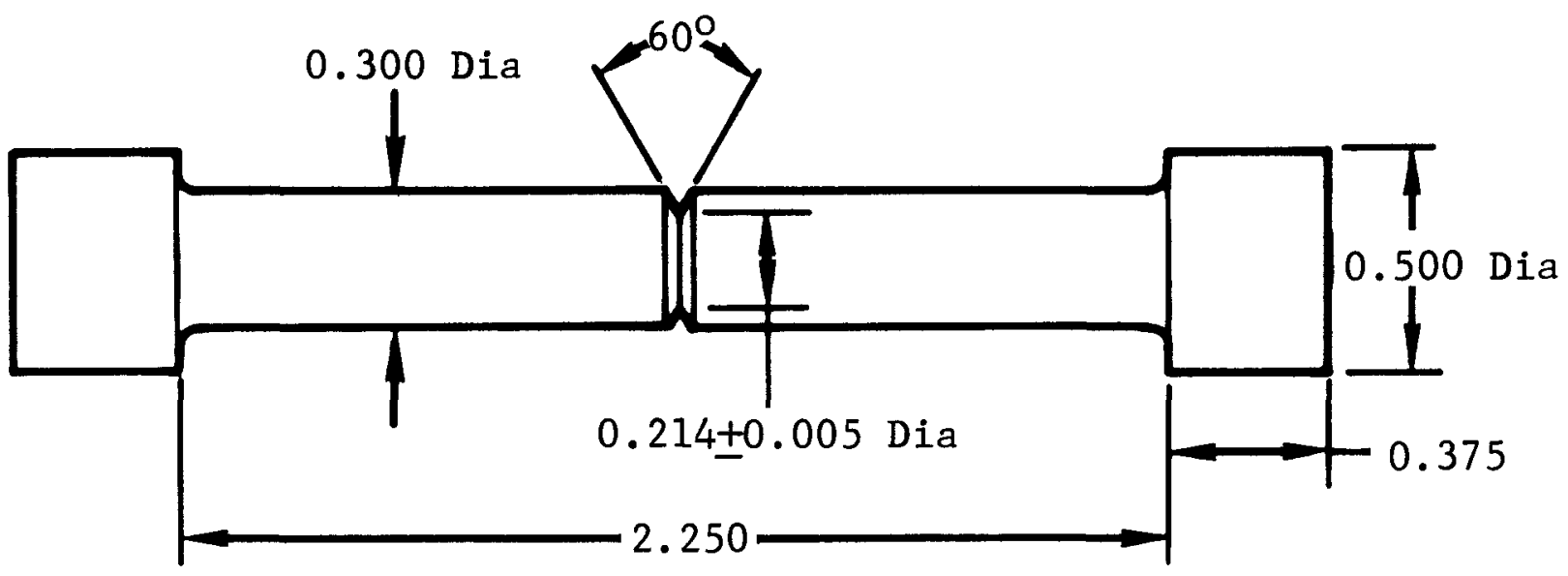

Dimensions in inches

Figure 1 Design of Buttonhead Specimens 
WANL and were of the notched sheet design shown in Figure 2. The notch dimensions of the buttonhead specimens are given in Table $I$.

Table I

NOTCH DIMENSIONS OF BUTTONHEAD SPECIMENS

\begin{tabular}{lccc}
\hline Material & S/N & $\begin{array}{c}\text { Notch Diameter } \\
\text { (in.) }\end{array}$ & $\begin{array}{c}\text { Root Radius } \\
\text { (in.) }\end{array}$ \\
\hline \multirow{3}{*}{ Incone1 718 } & I14 & 0.217 & 0.0014 \\
& I15 & 0.215 & 0.0014 \\
& I16 & 0.216 & 0.0013 \\
& I18 & 0.214 & 0.0015 \\
& I19 & 0.218 & 0.0014 \\
& I21 & 0.217 & 0.0013 \\
\hline \multirow{2}{*}{ Ti 5 A1 2.5Sn } & T44 & 0.214 & \\
& T45 & 0.215 & 0.0013 \\
& T46 & 0.215 & 0.0013 \\
& T47 & 0.214 & 0.0013 \\
& T48 & 0.215 & 0.0013 \\
& T49 & 0.215 & 0.0014 \\
A-286 & & & \\
& A1 & 0.216 & 0.0013 \\
& A2 & 0.209 & 0.0013 \\
& A3 & 0.213 & 0.0013 \\
& A4 & 0.209 & 0.0013 \\
& A5 & 0.215 & 0.0013 \\
\hline
\end{tabular}

The notch dimensions of the 301 SS specimens are given in Table II. The quantities $r_{1}$ and $r_{2}$ are the root radii on the two sides of the notch, $t_{1}$ and $t_{2}$ are the thicknesses at the sides of the notch, and $W$ is the width of the notch. 

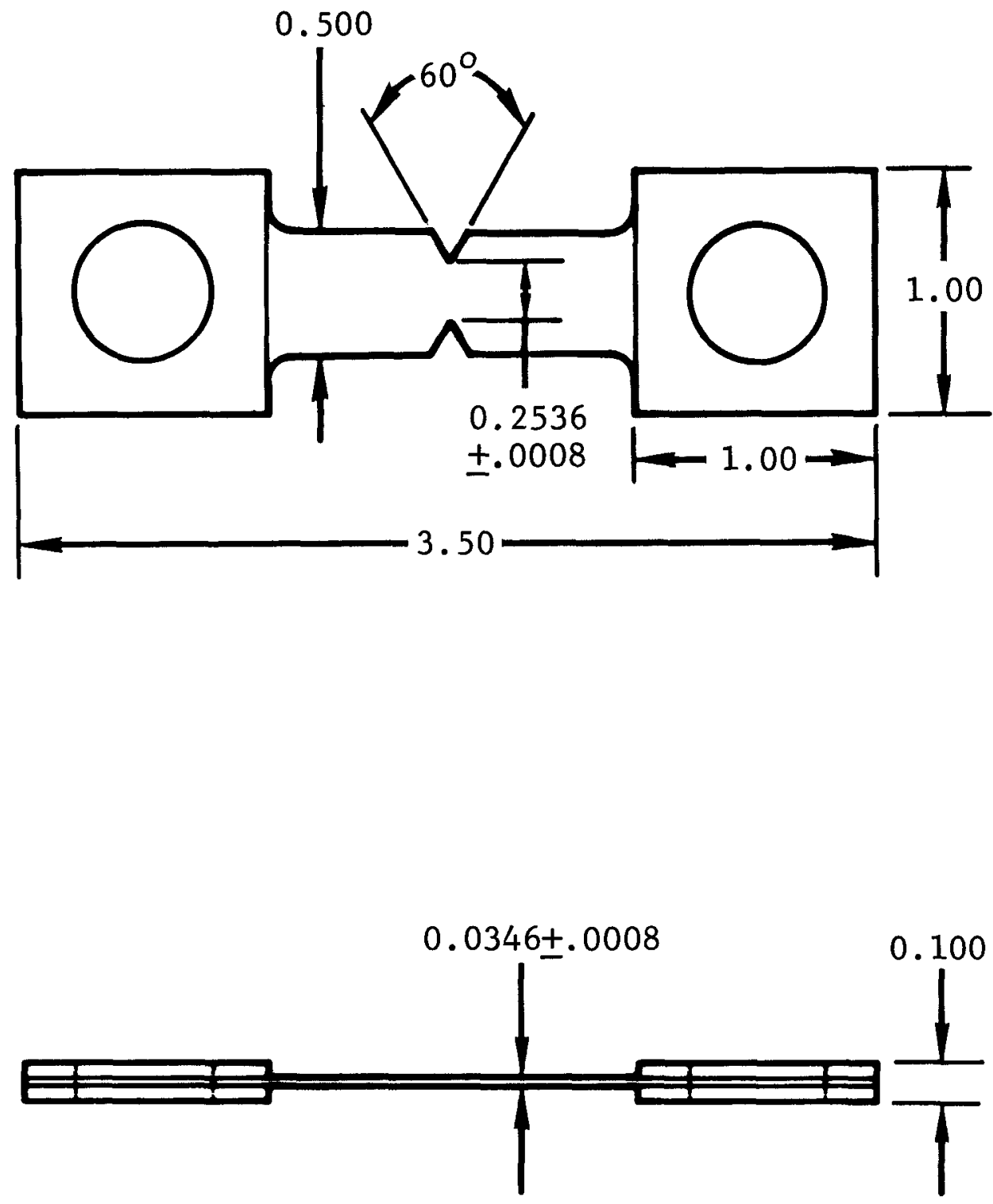

Dimension in inches

Figure 2 Design of Sheet Specimens 
Table II

NOTCH DIMENSIONS OF 301 SS SPECIMENS (in.)

\begin{tabular}{llllll}
\hline $\mathrm{S} / \mathrm{N}$ & $\mathrm{r}_{1}$ & $\mathrm{r}_{2}$ & $\mathrm{t}_{1}$ & $\mathrm{t}_{2}$ & $\mathrm{~W}$ \\
\hline & & & & & \\
1 & 0.0015 & 0.0015 & 0.0348 & 0.0346 & 0.2539 \\
2 & 0.0016 & 0.002 & 0.0355 & 0.0354 & 0.2528 \\
3 & 0.0016 & 0.0015 & 0.0341 & 0.0338 & 0.2536 \\
4 & 0.0016 & 0.0016 & 0.0353 & 0.0353 & 0.2528 \\
5 & 0.0016 & 0.0017 & 0.0349 & 0.0349 & 0.2531 \\
6 & 0.0017 & 0.0017 & 0.0350 & 0.0350 & 0.2544 \\
\hline
\end{tabular}

The chemical compositions of the test specimens are given in Table III and the heat treatments in Table IV.

Table III

CHEMICAL COMPOSITIONS OF TEST SPECIMENS

\begin{tabular}{|c|c|c|c|c|}
\hline Element & Inconel 718 & $\mathrm{Ti} 5 \mathrm{Al} 2.5 \mathrm{Sn}$ & $\mathrm{A}-286$ & $301 \mathrm{SS}$ \\
\hline C & 0.04 & 0.011 & 0.05 & 0.10 \\
\hline Mn & 0.10 & $<0.01$ & 1.68 & 0.99 \\
\hline Si & 0.13 & - & 0.65 & 0.45 \\
\hline $\mathbf{P}$ & 0.003 & - & 0.021 & 0.031 \\
\hline $\mathrm{S}$ & 0.006 & - & 0.009 & 0.010 \\
\hline $\mathrm{Cr}$ & 18.21 & - & 14.70 & 17.65 \\
\hline $\mathrm{Ni}$ & 52.54 & - & 26.43 & 7.1 \\
\hline Mo & 3.06 & - & 1.27 & 0.24 \\
\hline $\mathrm{Cu}$ & 0.01 & - & - & 0.10 \\
\hline $\mathrm{Cb} / \mathrm{Ta}$ & 5.22 & - & - & - \\
\hline $\mathrm{Ti}$ & 0.91 & 91.82 & 1.99 & - \\
\hline $\mathrm{Fe}$ & 19.02 & 0.14 & 52.54 & 73.33 \\
\hline A1 & 0.60 & 5.44 & 0.27 & - \\
\hline Co & 0.10 & 0.009 & - & - \\
\hline B & 0.0037 & - & 0.006 & - \\
\hline Sn & - & 2.47 & - & - \\
\hline $\mathrm{H}$ & - & 0.0094 & - & - \\
\hline 0 & - & 0.083 & - & - \\
\hline $\mathrm{N}$ & - & 0.009 & - & - \\
\hline V & - & - & 0.38 & - \\
\hline
\end{tabular}


Table IV

HEAT TREATMENTS OF TEST SPECIMENS

Material

Inconel 718
Heat Treatment

Forgings were solution annealed at $1950^{\circ} \mathrm{F}$, held $1 \mathrm{hr}$ and rapid air cooled per AGC Specs 90093 and 46604B. Following rough machining, the specimen blanks were aged at $1350^{\circ} \mathrm{F}$ for $8-10 \mathrm{hr}$, furnace cooled to $1200^{\circ} \mathrm{F}$, held for a total aging time of $20 \mathrm{hr}$, air cooled (AGC 46604).

Ti $5 \mathrm{Al} 2.5 \mathrm{Sn}$

Vacuum annealed at $1400^{\circ} \mathrm{F}$ for $1 \mathrm{hr}$, furnace cooled.

A-286

Solution heat treated at $1800^{\circ} \mathrm{F}$ for $1 \mathrm{hr}$, precipitation heat treated at $1300-1400^{\circ} \mathrm{F}$, held minimum of $16 \mathrm{hrs}$, air cooled.

Cold worked.

\subsection{Irradiation}

A total of 24 specimens, 6 of each material, was irradiated. The irradiation of the specimens, described in Reference 4, was performed during power cycles 110 and 111 of the Plum Brook Reactor (PBR) at the NASA Lewis Research Center.

The specimens were mounted in capsules which were then loaded in PBR test holes. Primary reactor water was flowed through the capsules during irradiation in order to maintain specimen temperatures of $125-150^{\circ} \mathrm{F}$. 
PBR power cycle 110 was initiated at 1448 on 26 June 1970 and terminated at 1040 on 9 July 1970. During the cycle, 655.6 megawatt-days were accumulated. During shutdown the capsules were rotated $180^{\circ}$ in order to decrease the fluence gradient across the specimens.

PBR power cycle 111 was started at 1753 on 11 July 1970 and terminated at 2242 on 27 July 1970. During the cycle, 764.8 megawatt-days were accumulated.

Thermal fluences on the specimens were measured with cobalt wires and fast fluences with nickel and titanium detectors. The thermal and fast $(E>1 \mathrm{MeV})$ fluences received by the specimens are given in Table $V$. The estimated uncertainty of the fluences at the $95 \%$ confidence level is $\pm 20 \%$.

Table V

NEUTRON FLUENCES RECEIVED BY TEST SPECIMENS

\begin{tabular}{lcc}
\hline Material & Thermal Fluence & $\begin{array}{c}\text { Fast F1uence } \\
\left(\mathrm{n} / \mathrm{cm}^{2}\right)\end{array}$ \\
\hline Incone1 718 & $1.4 \times 10^{21}$ & $1.5 \times 10^{20}$ \\
Ti 5A1 2.5Sn & $1.3 \times 10^{21}$ & $1.3 \times 10^{20}$ \\
A-286 & $1.4 \times 10^{21}$ & $1.5 \times 10^{20}$ \\
301 SS & $1.4 \times 10^{21}$ & $1.6 \times 10^{20}$ \\
\hline
\end{tabular}


The induced radioactivity of individual Inconel 718 , $\mathrm{Ti} 5 \mathrm{~A} 1$ 2.5Sn, and A-286 specimens were measured at 1 foot $4 \frac{1}{2}$ months after irradiation and found to be $42,0.75$, and $32 \mathrm{R} / \mathrm{hr}$, respectively. The dose rate from the $301 \mathrm{sS}$ specimens 8 months after irradiation was $15 \mathrm{R} / \mathrm{hr}$ at 1 foot.

\subsection{Experimental Apparatus}

The experimental apparatus used for these hydrogen embrittlement tests consisted of three systems: a tensile test machine, a high-pressure chamber, and a hydrogen-purification system.

An Instron Mode1 TTD was used to perform the tensile tests. The loading assembly of this machine was located inside a hot cell. Remote handling and testing of the highly radioactive specimens were accomplished by means of the hot cell manipulators and remote control console of the Instron.

The test chamber was constructed of 8 -in. Schedule 80 pipe of $316 \mathrm{~L}$ stainless steel. Wall thickness was $1 / 2$ in., and inside dimensions were approximately 7.6 in. diameter by 24 in. length. The pull rods entered the chamber through triple 0-ring seals on each end. Ports were provided for hydrogen gas and instrumentation inputs.

The two sections of the chamber were joined and sealed with a remote-disconnect clamp manufactured by Gray Tool Company. 
This operation was performed remotely by utilizing the Instron crosshead and a remote torque wrench. A photograph of the test chamber mounted on the Instron loading assemb1y appears in Figure 3.

The hydrogen used in these tests was required to meet MSFC SPEC-356A, which is defined below:

Maximum Allowed Impurities (ppm)

$\begin{array}{ccccccc}\mathrm{O}_{2}+\mathrm{A} & \mathrm{N}_{2} & \mathrm{CO} & \mathrm{CO}_{2} & \mathrm{CH}_{4} & \text { as } \mathrm{CH}_{4} & \mathrm{H}_{2} \mathrm{O} \\ 1 & 2 & 0.5 & 1 & 2 & 9 & 9\end{array}$

Commercial high-purity hydrogen, $99.995 \%$, was therefore passed through a purification system before introduction into the test chamber.

The purification system consisted of Engelhard catalytic deoxygenation units, activated charcoal and alumina adsorbents at $77^{\circ} \mathrm{K}$, and a $10-\mu$ filter. A schematic of the hydrogen purification and distribution system is given in Figure 4.

A rotary vacuum pump with Veeco foreline and liquid nitrogen traps was used to evacuate the test chamber prior to pressurization.

The purity of the hydrogen was measured with a Perkin-Elmer Model 880 gas chromatograph. Linde 5A molecular sieve and silica ge1 columns and a thermal conductivity detector were used in the chromatograph. Hydrogen samples could be taken directly from 


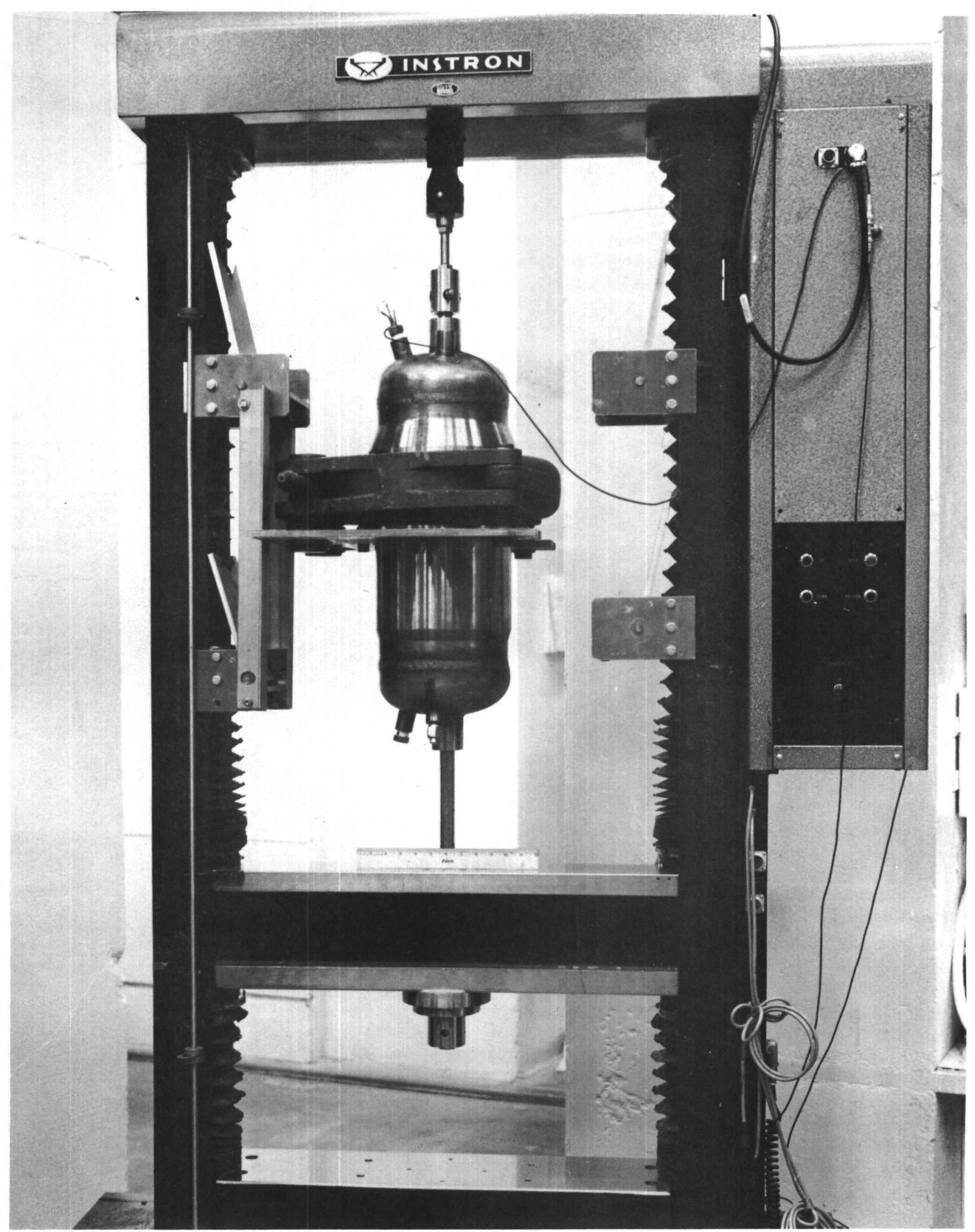

Figure 3 Test Chamber Mounted on Loading Assembly 


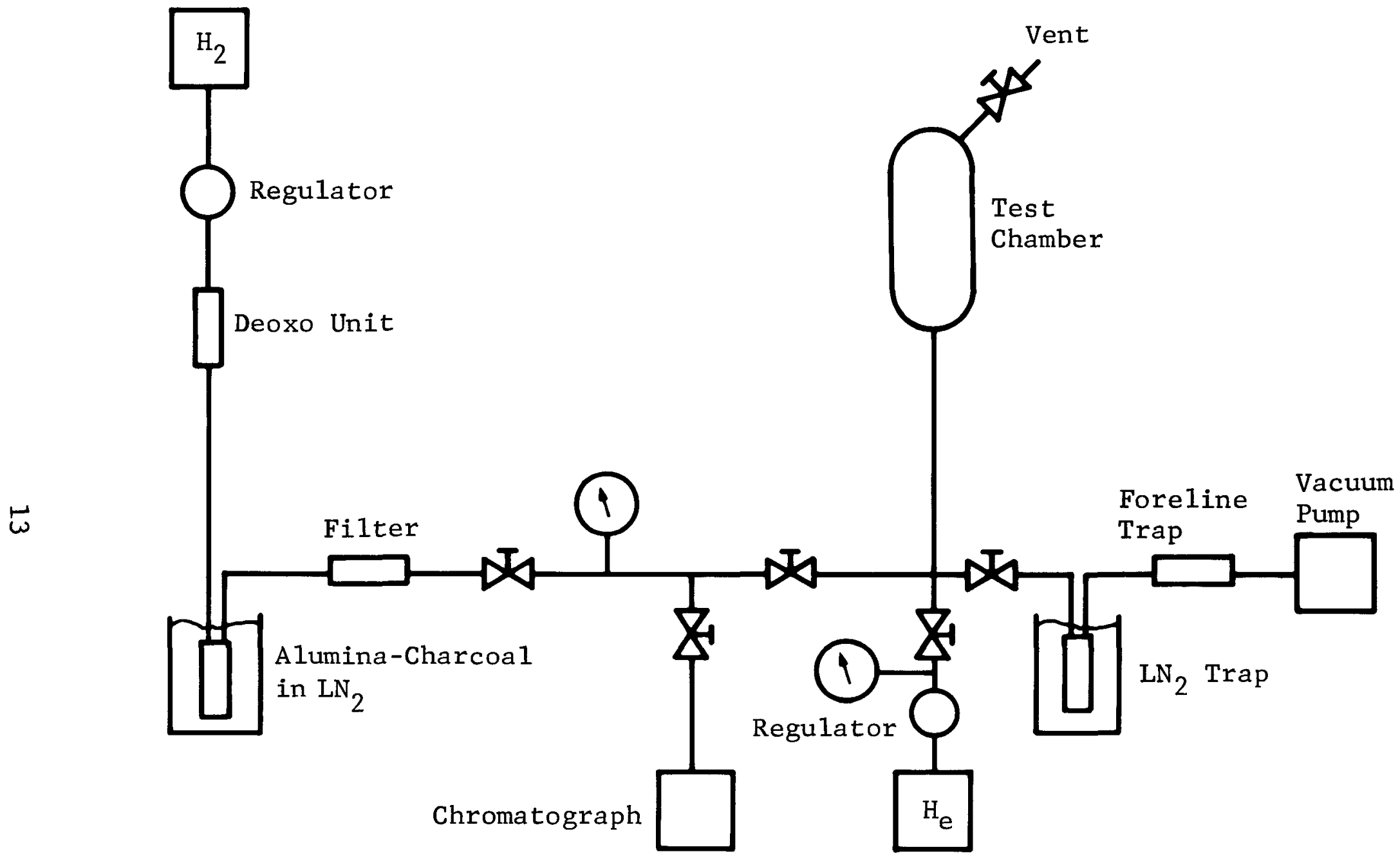

Figure 4 Schematic of Gas Distribution System 
either the hydrogen purification system or the pressurized test chamber.

The chromatograph was calibrated for the gases of interest by means of gas mixtures of known composition which were prepared with a gas proportioner. The minimum sensitivity for the permanent atmospheric gases was approximately $0.3 \mathrm{ppm}$. 2.4 Test Procedures

Slotted sample grips were employed for testing of the irradiated buttonhead specimens in order to facilitate loading. Axiality was found to be very poor when the slots were parallel; maximum bending strain due to the apparatus was $31.5 \%$ (Ref. 5). It was found, however, that when the slots were oriented in opposite directions the maximum bending strain at the center of the specimen was $3.5 \%$.

The grips were therefore mounted in the test chamber in the opposed configuration, and axiality of the entire tensile test system was measured. The maximum bending strain at the center of the specimen due to the apparatus was $7 \%$. The maximum allowed by test specifications was $9.2 \%$. A view of a specimen loaded in the grips is presented in Figure 5.

Analyses of the hydrogen gas were performed before initiation of tensile testing. Samples of hydrogen directly from the purification system and from the pressurized chamber were found to contain 


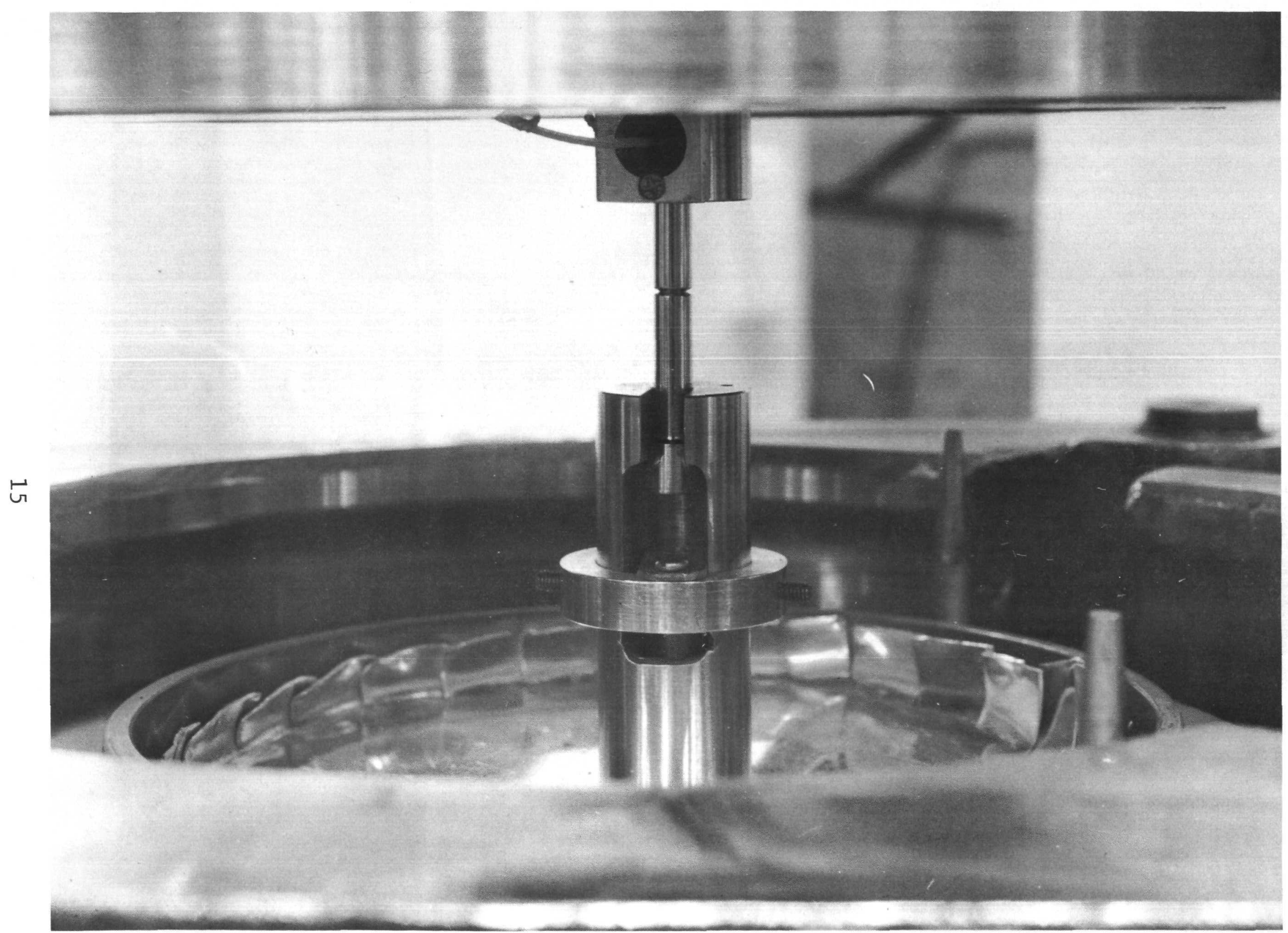

Figure 5 Buttonhead Specimen Loaded in Test Chamber 
no contaminants of $\mathrm{O}_{2}, \mathrm{~N}_{2}, \mathrm{CO}, \mathrm{CO}_{2}$, and $\mathrm{CH}_{4}$. Minimum sensitivity of the gas chromatograph was approximately $0.3 \mathrm{ppm}$. Water content of the hydrogen was found to be $0.6 \mathrm{ppm}$ by means of dew point measurements.

Gas analyses were performed periodically after initiation of tensile testing. Only trace amounts of contaminants were found in any of these tests.

Both evacuation and purging were used to prepare the test chamber for final hydrogen pressurization. The chamber was first evacuated to approximately 100 microns, then pressurized to 300 psi with high-purity helium. This pressure was then bled off, and the chamber was vacuum-pumped for a minimum of 8 hours. Final pressures of a few microns were attained. The chamber was then pressurized to 100 psi with hydrogen, bled off, and evacuated for 1 hour. This pressurization-evacuation cycle was repeated, and the chamber was then pressurized to 1500 psi with hydrogen.

Crosshead speeds of 0.014 and $0.0093 \mathrm{in./min}$ were used for the buttonhead and sheet specimens, respectively. These speeds correspond to a strain rate of approximately $0.0007 \mathrm{in./in./min} \mathrm{for}$ unnotched specimens.

Six specimens each of 301 SS, Ti $5 \mathrm{Al} 2.5 \mathrm{Sn}$, and A-286 were tested. Four of each were pulled in hydrogen at $1500 \mathrm{psi}$ and 
two of each in high-purity helium at $1500 \mathrm{psi}$; the latter served as controls. Only four specimens of Inconel 718 were pulled, two in both hydrogen and helium at 1500 psi. 


\section{RESULTS AND CONCLUSIONS}

The notch tensile strengths of the four types of irradiated alloys which were tested in 1500-psi helium and hydrogen are presented in this section. Unreduced areas were used to calculate notch tensile strengths from breaking loads.

\subsection{Ti $5 \mathrm{~A} 12.5 \mathrm{Sn}$}

The notch tensile strengths obtained for irradiated $\mathrm{Ti}$ 5Al 2.5Sn specimens in 1500-psi helium and hydrogen are presented in Table VI.

Table VI

NOTCH TENSILE STRENGTHS OF IRRADIATED

Ti 5A1 2.5Sn SPECIMENS

\begin{tabular}{clrcc}
\hline Spec. No. & Gas & $\begin{array}{c}\text { Ultimate } \\
\text { (1b) }\end{array}$ & $\begin{array}{c}\text { Strength } \\
\text { (ksi) }\end{array}$ & $\begin{array}{c}\text { \% Loss from } \\
\text { He }\end{array}$ \\
\hline T-48 & Helium & 6418 & 177 & - \\
T-45 & Helium & 6304 & 174 & - \\
T-44 & Hydrogen & 5988 & 166 & 5.4 \\
T-47 & Hydrogen & 5930 & 165 & 6.0 \\
T-49 & Hydrogen & 5949 & 164 & 6.5 \\
T-46 & Hydrogen & 5668 & 156 & 11.1 \\
\hline
\end{tabular}

The average notch tensile strength was reduced from $175 \mathrm{ksi}$ in helium to $163 \mathrm{ksi}$ in $1500 \mathrm{psi}$ hydrogen, or an average loss of $6.9 \%$. 
Several unirradiated $\mathrm{Ti} 5 \mathrm{Al} 2.5 \mathrm{Sn}$ specimens were tested in air, helium, and 1500-psi hydrogen during checkout of the experimental apparatus. Average notch tensile strengths were $175 \mathrm{ksi}$ in helium and air and $165 \mathrm{ksi}$ in 1500-psi hydrogen for an average loss of $5.7 \%$ in hydrogen.

The notch tensile strength of unirradiated $\mathrm{Ti} 5 \mathrm{Al} 2.5 \mathrm{Sn}$ has been observed by other investigators to exhibit losses of $19 \%$ at a hydrogen pressure of 10,000 psi (Ref. 1) and $10 \%$ at 1400 psi (Ref. 3).

\section{$3.2 \quad \underline{A-286}$}

The notch tensile strengths obtained for irradiated A-286 specimens in 1500-psi helium and hydrogen are presented in Table VII.

Table VII

NOTCH TENSILE STRENGTHS OF IRRADIATED A-286 SPECIMENS

\begin{tabular}{llrcc}
\hline Spec. No. & Gas & $\begin{array}{c}\text { Ultimate Load } \\
\text { (1b) }\end{array}$ & $\begin{array}{c}\text { Strength } \\
\text { (ksi) }\end{array}$ & $\begin{array}{c}\text { \% Change } \\
\text { from He }\end{array}$ \\
\hline A-6 & Helium & 10,065 & 270 & - \\
A-5 & Helium & 9,850 & 271 & - \\
A-4 & Hydrogen & 9,565 & 279 & +3.1 \\
A-3 & Hydrogen & 9,707 & 272 & +0.55 \\
A-1 & Hydrogen & 9,945 & 271 & +0.18 \\
A-2 & Hydrogen & 9,613 & 280 & +3.5 \\
\hline
\end{tabular}


The average notch tensile strength of irradiated A-286 specimens increased from $270 \mathrm{ksi}$ in helium to $275 \mathrm{ksi}$ in 1500-psi hydrogen, or an average increase of $1.8 \%$. This slight increase is probably the result of using the unreduced area in the calculation of notch tensile strength.

Unirradiated specimens have been reported to 10 se $3 \%$ in notch tensile strength at a hydrogen pressure of $10,000 \mathrm{psi}$ (Ref. 1) and to be unaffected at 1400 psi (Ref. 3).

$3.3 \quad 301$ SS

Notch tensile strengths of irradiated 301 SS specimens in 1500-psi helium and hydrogen are given in Table VIII. Data for specimen 301 SS-1 are not reported, since it was damaged during the loading procedure.

Table VIII

NOTCH TENSILE STRENGTHS OF IRRADIATED 301 SS SPECIMENS

\begin{tabular}{clrcc}
\hline Spec. No. & Gas & $\begin{array}{r}\text { U1timate Load } \\
\text { (1b) }\end{array}$ & $\begin{array}{c}\text { Strength } \\
\text { (ksi) }\end{array}$ & $\begin{array}{c}\text { \% Loss } \\
\text { from He }\end{array}$ \\
\hline & & & & \\
-5 & Helium & 2180 & 247 & - \\
-4 & Helium & 2198 & 246 & - \\
-2 & Hydrogen & 427 & 47.6 & 81 \\
-6 & Hydrogen & 440 & 49.4 & 80 \\
-3 & Hydrogen & 404 & 46.9 & 81 \\
\hline
\end{tabular}


The average notch tensile strength of irradiated 301 SS specimens was reduced from $246 \mathrm{ksi}$ to $48 \mathrm{ksi}$, or an average loss of $81 \%$.

There are no data in the literature on the effect of hydrogen on the notch tensile strength of 301 SS.

\subsection{Incone1 718}

The notch tensile strengths of irradiated Inconel 718 specimens in 1500-psi helium and hydrogen are reported in Table IX.

Table IX

NOTCH TENSILE STRENGTHS OF IRRADIATED INCONEL 718 SPECIMENS

\begin{tabular}{clccc}
\hline Spec. No. & Gas & $\begin{array}{c}\text { Ultimate Load } \\
\text { (1b) }\end{array}$ & $\begin{array}{c}\text { Strength } \\
\text { (ksi) }\end{array}$ & $\begin{array}{c}\% \text { Change } \\
\text { from He }\end{array}$ \\
\hline I-16 & Helium & 10,925 & 298 & - \\
I-19 & Helium & 10,720 & 287 & - \\
I-15 & Hydrogen & 10,490 & 289 & -1.2 \\
I-21 & Hydrogen & 10,963 & 296 & +1.2 \\
\hline
\end{tabular}

The notch tensile strength of irradiated Inconel 718 specimens had an average value of $292 \mathrm{ksi}$ in helium and exhibited no reduction in $1500-p s i$ hydrogen.

Hydrogen embrittlement of Inconel 718 has been investigated in several studies (Refs. 1,2,3). Reductions in notch tensile 
strength varying from 0 to $54 \%$ were observed over hydrogen pressures from 100 to $10,000 \mathrm{psi}$. The degree of embrittlement increased with increasing hydrogen pressure, although it was not a strong function at pressures greater than a few hundred psi. Walter and Chandler (Ref. 2) tentatively concluded that the degree of embrittlement was also related to the heat treatment of the Inconel 718 specimens.

Seven unirradiated Inconel 718 specimens of the same material heat and with the same heat treatment as the irradiated specimens were tested in hydrogen during the present study. Average reductions in notch tensile strength of $6.9 \%$ and $8.3 \%$ were observed at hydrogen pressures of 500 and 1500 psi, respectively. Since no specimens were tested in an inert atmosphere, a tensile strength of $289 \mathrm{ksi}$, which had been previously obtained for similar specimens (Ref. 3), was used as a reference value.

A summary of the available hydrogen-embrittlement data on unirradiated Inconel 718 specimens with different heat treatments appears in Table $\mathrm{X}$. Solution-annealing temperatures varied from $1750^{\circ} \mathrm{F}$ to $1950^{\circ} \mathrm{F}$; while the subsequent aging procedures for the different studies were quite similar. Although comparisons are complicated by the different hydrogen pressures of the several 
Table X

SUMMARY OF HYDROGEN-EMBRITTLEMENT DATA ON UNIRRADIATED INCONEL 718

\begin{tabular}{|c|c|c|c|c|c|c|c|c|}
\hline \multirow{3}{*}{ Ref. } & \multirow{3}{*}{$\begin{array}{l}\text { Hydrogen } \\
\text { Pressure } \\
\text { (psi) }\end{array}$} & \multirow{3}{*}{$\begin{array}{l}\% \text { Reduction } \\
\text { of Notch } \\
\text { Tensile } \\
\text { Strength }\end{array}$} & \multicolumn{6}{|c|}{ hieat Treatment } \\
\hline & & & \multicolumn{2}{|c|}{ Solution Annealing } & \multicolumn{2}{|c|}{ First Aging } & \multicolumn{2}{|c|}{ Second Aging } \\
\hline & & & ${ }^{o} F$ & Min & ${ }^{O} \mathrm{~F}$ & $\mathrm{Hr}$ & ${ }^{O_{F}}$ & $\mathrm{Hr}$ \\
\hline 1 & 10,000 & 54 & 1750 & 60 & 1325 & 8 & 1150 & 10 \\
\hline 3 & 500 & 34 & 1800 & 60 & 1325 & 8 & 1150 & 12 \\
\hline 1 & 1,000 & $40 *$ & 1850 & 60 & 1360 & 10 & 1175 & 10 \\
\hline \multirow[t]{3}{*}{2} & 1,000 & 9.1 & \multirow{3}{*}{1900} & \multirow{3}{*}{20} & \multirow{3}{*}{1400} & \multirow{3}{*}{11} & \multirow{3}{*}{1200} & \multirow{3}{*}{9} \\
\hline & 1,500 & 10.2 & & & & & & \\
\hline & 2,000 & 15.3 & & & & & & \\
\hline 3 & 500 & $50 * *$ & $\begin{array}{l}1800 \\
1950\end{array}$ & $\begin{array}{l}60 \\
60\end{array}$ & $\begin{array}{l}1325 \\
1350\end{array}$ & $\begin{array}{c}8 \\
8-10\end{array}$ & $\begin{array}{l}1150 \\
1200\end{array}$ & $\begin{array}{c}12 \\
10-12\end{array}$ \\
\hline \multirow{2}{*}{$\begin{array}{l}\text { Present } \\
\text { Study }\end{array}$} & 500 & 6.9 & \multirow[t]{2}{*}{1950} & \multirow[t]{2}{*}{60} & \multirow[t]{2}{*}{1350} & \multirow[t]{2}{*}{$8-10$} & \multirow[t]{2}{*}{1200} & \multirow[t]{2}{*}{$10-12$} \\
\hline & 1,500 & 8.3 & & & & & & \\
\hline
\end{tabular}

* Material did not meet AMS composition specifications for Inconel 718.

**Mate rial received double heat treatment with $1950^{\circ} \mathrm{F}$ anneal and aging following $1800^{\circ} \mathrm{F}$ anneal and aging. 
studies, the data, with one exception, demonstrate a trend to lower degrees of embrittlement at higher solution annealing temperatures.

Hydrogen-embrittlement data on the doubly heat-treated specimens are anomalous. They appeared to be relatively unaffected by the second heat treatment, since the $50 \%$ effect observed was approximately that expected for specimens receiving the $1800^{\circ} \mathrm{F}$ heat treatment on $1 \mathrm{y}$. The $40 \%$ effect demonstrated by the $1850^{\circ} \mathrm{F}$ specimens was somewhat higher than that expected, if a correlation between embrittlement and annealing temperature is assumed. It should be noted, however, that the material composition of these specimens did not meet AMS specifications for Inconel 718.

The hydrogen embrittlement exhibited by the unirradiated Inconel 718 specimens in the present study was thus approximately that expected for specimens with a $1950^{\circ} \mathrm{F}$ annealing temperature. However, the irradiated specimens, with identical material composition and heat treatment, were unaffected by 1500-psi hydrogen . The two possible explanations for this phenomenon are corrosion and radiation damage.

The irradiated Inconel 718 specimens exhibited severe corrosion in localized areas. Since this material is corrosionresistant, it has been postulated that the corrosion was due to 
surface contamination of the specimens. However, since most theories of mechanisms of hydrogen embrittlement espouse hydrogen interactions at fresh metallic surfaces formed during stress, inhibition of embrittlement by outer surface contamination is difficult to understand.

Neutron irradiation is known to produce effects in alloys which are similar to metallurgical techniques for manipulation of their properties, i.e., cold-working, solutionhardening, quenching, and heat treatment. In particular, similarities have been observed in precipitation-hardened alloys between radiation effects and heat treating at temperatures below normal heat-treating temperatures.

Since the degree of embrittlement of Inconel 718 appears to be related to solution-annealing temperature, neutron irradiation may produce similar effects in the material which inhibit hydrogen embrittlement. However, an acceptable explanation for the lack of embrittlement in these specimens can only be furnished by further testing. 


\section{REFERENCES}

1. Walter, R. J. and Chandler, W. T., "Effects of HighPressure Hydrogen on Metals at Ambient Temperature," Rocketdyne Report No. R-7780-1, February 1969.

2. Walter, R. J. and Chandler, W. T., "Effect of Hydrogen Environment on Inconel 718 and Ti-6Al-4V Under Simulated J-2 Engine Operating Conditions," Rocketdyne Report No. R-7920, June 1969 .

3. Walter, R. J., Hayes, H. G., and Chandler, W. T., "Mechanical Properties of Inconel 718, Waspalloy, A-286, and Ti-5A12.5Sn ELI in Pure Gaseous $\mathrm{H}_{2}$," Rocketdyne Report No. R-8187, April 1970.

4. "Data Report of NERVA Materials Irradiation, Test Numbers 37 NR0-090, -091, -092, and -093 (Rev. 1)," letter from Don Winterich, Lewis Research Center, Plum Brook Station to Mel Davidson, Aerojet Nuclear Systems Company, 1 October 1970 .

5. "Axiality Development Summary, Application of Preliminary Standard Procedure, RE-1," Memo from D. A. Brown to M. J. Davidson, Aerojet Nuclear Systems Company, 29 October 1970. 
DISTRIBUTION

Addressee

No. of Copies

Headquarters USAF

Washington, D. C. 20330

Attention: Mr. W. D. Downs (AFRDQSN) 1

SNSO-Washington

Division of Reactor Development

U.S.A.E.C.

Germantown, Maryland 20767

Attention: Mr. W. S. Schieb

SNSO-Cleveland

21000 Brookpark Road

Cleveland, Ohio 44100

Attention: Mr. J. J. Lombardo

Aerojet-Nuclear Systems Company

P. 0. Box 15847

Sacramento, California 95813

Attention: Mr. T. Redfield

Westinghouse Astronuclear Laboratory

P. 0. Box 10864

Pittsburgh, Pennsylvania 15236

Attention: Mr. T. P. Merrick

SNSO-C Resident office

Aerojet-Nuclear Systems Company

Sacramento, California 95813

Attention: Mr. M. M. Carness

Plum Brook Station

Lewis Research Center

Sandusky, Ohio 44870

Attention: Mr. Ralph Stein

Aerojet-Nuclear Systems Company

P. 0. Box 15847

Technical Library

B1dg. 2015, Dept. 2410

Sacramento, California 95813 


\section{DISTRIBUTION (cont'd)}

Addressee

No. of Copies

Radiation Effects Information Center

Battelle Memorial Institute

505 King Avenue

Columbus, Ohio 43201 